\title{
911.5:528.5
}

\author{
- гульськ \\ ьвівський н ціон льний університет імені в н \\ вул. . орошенк , 41, м. ввів, 79000, кр їн
}

прикл ді двох ключових ділянок розкрито особливості л ндш фтного сусідств в з хідній ч стині лого олісся т причини його формув ння. тупінь сумісного виявлення тих чи інших урочищ визн ч ли як ч стку від усіх прит м нних їм межув нь, прийнятих з $100 \%$. ведені в т блицях пок зники сумісного виявлення тих чи інших урочищ ілюструють, які л ндш фтні комплекси тр пляються один з одним, які не поєднуються між собою, т кож відобр ж ють міру вірогідності цього зв'язку. 'ясов но, що в меж х тинської ключової ділянки кожен вид урочищ м $є$ велику кількість сусідів, тому низькі пок зники ч стоти виявлення 3 кожним з них. ключовій ділянці, з кл деній у смовому обужжі, низк урочищ м є м лу кількість сусідів і яскр во вир женого домін нт . е л ндш фтні комплекси горбів і днищ лощин т б лок. ючи відомості про х р ктерні сусідств , можн з'ясовув ти видову н лежність л ндш фтного комплексу без польових досліджень. изн чено головні н прями з стосув ння зн нь про л ндш фтні сусідств : дослідження генезису л ндш фтних комплексів, фізико-геогр фічне р йонув ння, л ндш фтн індик ція, тем тичне опр цюв ння д них дист нційного зондув ння емлі, геогр фічне прогнозув ння.

лючові слов : ле олісся, л ндш фтний комплекс, л ндш фтний м люнок, л ндш фтне сусідство, сумісне виявлення.

ндш фтне сусідство - систем послідовних поєдн нь л ндш фтних контурів, що утворюють л ндш фтний м люнок [2]. кл дн, проте з вжди з кономірн систем л ндш фтного сусідств формується під впливом усього комплексу чинників л ндш фтної диференці ції. поєдн ння вплив ють як геологічні т зон льно-клім тичні умови, т к і чинник ч су.

дн $з$ перших пр ць, у якій розглянуто систему л ндш фтного сусідств , н лежить . реобр женському. лі теоретико-методичну основу вивчення геогр фічного сусідств розробляли . ікторов [2,3], . еренчук, . ковськ , . опчієв [4], . в шутін і . ікол єв [5, 6], . имонов [8, 9], . рідл нд [10] т ін. к чи ін кше цього пит ння торк ються втори пр ць $[1,7,11] \mathrm{T}$ ін.

н ліз л ндш фтного сусідств необхідний для вирішення низки теоретичних i пр ктичних геогр фічних з вд нь. ослідовність межув нь л ндш фтних комплексів ( ) допом ге розуміти їхній генезис т розкрив ти геохімічні зв'язки між ними. росторові поєдн ння т кож використовують у р зі виділення фізико-геогр фічних $\mathrm{p}$ йонів.

сфері тем тичного опр цюв ння д них дист нційного зондув ння емлі розт шув ння у системі л ндш фтного сусідств - одн 3 дешифрув льних озн к. собливо цінн $з$ сл бкого відобр ження л ндш фтних комплексів н еро- чи космознім-

(C) гульськ ., 2012 
к х, спричиненого, н прикл д, господ рською діяльністю (сільськогоспод рськими угіддями, н селеними пункт ми, підприємств ми), несприятливими метеоумов ми знім ння, нечіткими природними меж ми, подібністю зовнішнього вигляду кількох

усідство в т кому вип дку виконує функцію умовних імовірностей виявлення зобp ження цього типу в певному тон льному (колірному) чи текстурному оточенні і $€$ пріорною інформ цією про просторову структуру вищих р нгів. остовірно відомі бо впізн ні н еро- т космознімк х л ндш фтні комплекси можуть бути індик тор ми тих л ндш фтних комплексів, які прямо бо опосередков но з ними межують, одн к н момент знім ння не виявлені бо прихов ні.

им лі перспективи відкрив ються й для вирішення з вд нь геогр фічного прогнозув ння. $\quad$ то природних процесів формують х р ктерні л ндш фтні м люнки, послідовність просторового сусідств нерідко відобр ж є їхні зміни в ч сі, тобто різні ст дії одного й того ж процесу.

ерелічені вище обст вини визн чили кту льність дослідження ймовірності виявлення тих чи інших $\quad$ н конкретній території і в певному л ндш фтному оточенні.

ижче н ведено особливості л ндш фтного сусідств , виявлені н ключових ділянк х, розміщених у з хідній ч стині лого олісся, с ме - у б сейн х річок ерев'янк , іл , ощ нк ( тинський л ндш фт) і в б сейн х кв ряви т вині (л ндш фт смового обужжя, цошинсько- мереківськ ключов ділянк ). кремі з виявлених сусідств н леж ть до 3 г льновідомих, одн к 3 результ т ми н ших досліджень визн чено індивіду льні для кожної території їхні кількісні п р метри.

сновою роботи були л ндш фтні к рти, скл дені н рівні урочищ. тупінь зустрічності визн ч ли т к: 3 г льну кількість межув нь урочищ одного виду з усім урочищ ми-сусід ми прийм ли з $100 \%$. лі для кожного виду з'ясовув ли його зустрічність (у відсотк х) з кожним іншого виду, якщо у них є спільні межі.

ля інших обчислюв льних робіт (вип дковості чи з кономірності сусідств , міри близькості, питомої протяжності) використ но методику, яку з пропонув в . имоНОВ [8].

ля впорядкув ння кількісної інформ ції створено низку т бличних моделей (площ і довжин л ндш фтних ре лів, л ндш фтного сусідств (у відсотк х), ч стки спільних меж (у відсотк х), зн чущості ділянки спільних меж (з ур хув нням питомої протяжності)).

ндш фтн структур ключової ділянки, з кл деної в тинському л ндш фті, вирізняється великою кількістю як індивіду льних, т к і типологічних одиниць. ізном нітні процеси, що тут відбув лись, з лишили свої сліди у вигляді відкл дів різного віку і генезису, що позн чилось н х р ктері рельєфу, особливостях грунтів т рослинності.

я територія предст влен н йбільш х р ктерними для лого олісся л ндш фтними місцевостями: 1) погорбов них з ндрових рівнин; 2) сл бкохвилястих денуд ційних рівнин; 3) міжрічкових знижень.

ля урочищ місцевості з ндрових рівнин х р ктерне поєдн ння дернового і підзолистого елемент рних грунтових процесів мінливої інтенсивності, з лежної від форми мезорельєфу, гр нулометричного скл ду т потужності відкл дів. собливістю місцевості є піщ ні горби т п см з дерново-сл бкопідзолистими глеюв тими грунт ми. осить зн чні площі з йняті урочищ ми підвищених плоских поверхонь 3 дерновосл бкопідзолистими глейовими супіщ ними грунт ми, дерново-середньопідзолистими глеюв тими супіщ ними грунт ми і дерново-середньопідзолистими глейовими грун- 
т ми. ля них х р ктерні хвилясті обриси і невизн чен форм . одноч с простежен усп дков н від н пряму міжрічкових знижень субширотн орієнт ція.

ісцевість сл бкохвилястих денуд ційних рівнин виділяється н йменшими розміp ми і фр гмент рним поширенням. рочищ, які їі утворюють, сформув лись бо н підвищеннях крейдової поверхні, бо в зниженнях рельєфу, де к рбон тні породи (перев жно лучні мергелі) перекриті незн чною товщею флювіогляці льних бо озерних відкл дів. они м ють середні розміри, близьку до ов льної форму і витягнутість із з ходу н схід. ут поширені дернові к рбон тні бо лучні к рбон тні грунти легкосуглинкового, рідше середньосуглинкового гр нулометричного скл ду.

ісцевість міжрічкових знижень предст влен урочищ ми озерного, люві льного, водно-льодовикового генезису. оходження визн чило розміри , їхню орієнт цію, просторову приуроченість, х р ктер грунтотворення. р ктеристики грунтового профілю (потужність грунтового профілю, потужність гумусового горизонту, вологість, гр нулометричний скл д, н явність чи відсутність оглеєння, т кож його інтенсивність) тісно з леж ть від гіпсометричного рівня. Йвищі місцеположення з йняті урочищ ми з дерновими грунт ми, н йнижчі - урочищ ми з торфово-болотними грунт ми і торфовищ ми низинними. проміжних рівнях сформув лись 3 лучними і лучноболотними грунт ми.

нш л ндш фтн будов ключової ділянки, що розт шов н у л ндш фті смового обужжя. ї головними елемент ми є урочищ привододільних поверхонь п сом т схилів різної експозиції. ерші з них м ють вузьку витягнуту форму, звивисті обриси, світло-сірі лісові грунти н лесоподібних суглинк х. ругі суттево більші з розмір ми, т кі ж звивисті з формою, вкриті світло-сірими, сірими т темно-сірими змитими грунт ми.

н чні площі прип д ють тут і н урочищ плоских днищ міжп смових знижень, укритих осушеними дерновими, лучними і лучно-болотними глейовими к рбон тними грунт ми. і м ють перев жно з хідно-східне простяг ння, що відповід є н пряму орієнт ції п сом. р ктерною рисою їхньої геометрії є великі розміри, витягнутість, сл бк звивистість.

обох ключових ділянк х урочищ великих розмірів вирізняються н йбільшою довжиною контуру. , н вп ки, урочищ м лих розмірів м ють м лу довжину межової лінії. инятком є тільки ті , яким вл стиві вузькі видовжені бо розг лужені обриси. им більш довжин зовнішнього контуру л ндш фтного комплексу, тим більше сусідів він м є. им більшу кількість сусідів м є те чи інше урочище, тим менш вірогідність н явності серед них перев ж ючого з зустрічністю.

меж $\mathrm{x}$ тинської ключової ділянки кожен вид урочищ м $є$ велику кількість сусідів, що зумовило низькі пок зники ч стоти зустрічності з кожним з них (т бл. 1). я особливість пов'яз н з різном нітністю чинників л ндш фтогенезу, їхньою ч стою повторюв ністю в просторі, досить великими розмір ми перев жної більшості л ндш фтних ре лів, зн чною звивистістю, отже, довжиною контурів.

ільш-менш вир женого сусід -домін нт м ють тільки чотири види урочищ $-3,9$, 10, 20. ля виду 3 - підвищені плоскі поверхні з дерново-сл бкопідзолистими глейовими зв'язнопіщ ними грунт ми - т ким сусідом є щені поверхні з дерновими глибокими зв'язнопіщ ними грунт ми; відсоток сумісної зустрічності - 33,4. опри невелике зн чення ця величин є пок зовою, оскільки відобр ж є особливості розподілу грунтових відмін по гіпсометричних рівнях у меж х з ндрової рівнини лого олісся. вищих висотних рівнях і в умов х більшої потуж- 
ності водно-льодовикових відкл дів формув лись дерново-сл бкопідзолисті грунти, н суміжних з ними дещо нижчих висотних рівнях і в меншій з потужністю товщі флювіогляці лу - дернові грунти.

ля виду 9 - поверхні горбів з дерново-к рбон тними грунт ми - сусідом-домін нтом $є$ виду 12 - знижені плоскі поверхні з лучними к рбон тними грунт ми. умісн зустрічність - 37,5 \% вип дків з усіх з фіксов них сусідств. е сусідство т кож відобр ж є перебіг грунтотворного процесу, проте вже н позб влених флювіогляці льних відкл дів ділянк х л ндш фту. омітні нині згорблення верхньокрейдової поверхні є н слідком більшої їі міцності н цих ділянк х і меншого ступеня звітреності.

умов х меншої потужності елювію сформув лись короткопрофільні дернові к рбон тні грунти, тоді як у товщі елювію більшої потужностості - потужніші лучні к рбон тні грунти.

30,7 \% вип дків між собою межують урочищ виду 10 - підвищені поверхні 3 дерновими глибокими легкосуглинковими грунт ми н флювіогляці льних відкл д х, підстелених лучним мергелем, і урочищ виду 13 - сл бкопідвищені поверхні з дерновими глибокими зв'язнопіщ ними грунт ми н флювіогляці льних відкл д х. ке сусідство відобр ж є х р ктерне для лого олісся чергув ння ділянок з більш і менш припіднятою верхньокрейдовою поверхнею і відповідною цьому потужністю пухких відкл дів. місцевості сл бкохвилястих денуд ційних рівнин н припіднятих ділянк х корінного фунд менту товщ відкл дів т лих льодовикових вод менш , і н гр нулометричний скл д м теринської породи вплив ли як піски, т к і глинисті продукти звітрення мергелю. рунт, відповідно, легкосуглинковий. опущених місцях корінного фунд менту товщ пісків більш і тільки вони визн ч ли гр нулометричний скл д м теринської породи. ін, відповідно, зв'язнопіщ ний.

ост тньо тісне сусідство виду 20 - низькі поверхні з лучно-болотними грунт ми, з виду 18 - знижені плоскі поверхні з лучними глейовими грунт ми (сумісн зустрічність - 40,0 \%), є н слідком розміщення обох урочищ у колишній озерній улоговині. ліпше дренов них периферійних їі ділянк х сформув лись лучні грунти, н більш з глиблених і гірше дренов них ділянк х до дернового грунтотворного процесу дод вся болотний.

р ктер т вз ємні поєдн ння урочищ цошинсько- мереківської ключової ділянки визн чили т кі л ндш фтотворні процеси, як лесон гром дження і збереження його н н йбільш припіднятих форм х рельєфу - п см х, діяльність т лих льодовикових вод і їхні відкл ди, ерозійно- кумулятивн діяльність р. вині т іiі приток, денуд ція і близьке з ляг ння до поверхні верхньокрейдяних відкл дів.

вдяки зн чній площі контурів т довжині меж більшість видів урочищ ключової ділянки т кож м є велику кількість сусідів. йбільше - урочищ виду 10 - припідняті хвилясті поверхні з лучними к рбон тними грунт ми, які м ють 11 урочищ-сусідів (т бл. 2). і природні комплекси видовжені з формою, тр пляються у різних ч стин х місцевості, тому утворюють н йрізном нітніші комбін ції з іншими природними комплекс ми. одного сусід менше м ють урочищ виду 5 - підвищені сл бкохвилясті межиріччя з сірими лісовими глеюв тими грунт ми. великої кількості дотичних урочищ, зрозуміло, нем сусід -домін нт . йбільший відсоток сумісної зустрічності з якимось із урочищ у першому вип дку ст новить 17,65, у другому - 28,26.

ирокий розкид сусідств урочищ міжп смових знижень і днищ потоків ( $14,15)$ спричинений тим, що ці л ндш фтні комплекси одн ково поєдн ні як з прилеглими схил ми, т к із яр ми т лощин ми, що у них вп д ють. 
ндш фтні сусідств тинської ключової ділянки, \% сумісної зустрічності

\begin{tabular}{|c|c|c|c|c|c|c|c|c|c|c|c|c|c|c|c|c|c|c|c|c|c|c|c|}
\hline $\begin{array}{c}\text { ид } \\
\text { урочи- } \\
\text { щ }\end{array}$ & 1 & 2 & 3 & 4 & 5 & 6 & 7 & 8 & 9 & 10 & 11 & 12 & 13 & 14 & 15 & 16 & 17 & 18 & 19 & 20 & 21 & 22 & 23 \\
\hline 1 & & 11,0 & & 3,7 & & 11,0 & 18,6 & 3,7 & 3,7 & 3,7 & & 7,4 & 11,0 & 14,8 & & & & 7,4 & & & 3,7 & & \\
\hline 2 & 8,9 & & 2,9 & 2,9 & 5,9 & & 20,7 & 2,9 & & 2,9 & 29 & 29 & 8,9 & 11,9 & 29 & & 29 & 5,8 & & & 8,9 & & 5,8 \\
\hline 3 & & 83 & & 8,3 & 16,8 & & & & & & & & 33,4 & 8,3 & & & & 8,3 & 8,3 & & & 8,3 & \\
\hline 4 & 5,9 & 5,9 & 5,9 & & & 5,9 & & 5,9 & & & 5,9 & & 5,9 & 5,9 & 5,9 & & & 17,6 & 11,7 & & 5,9 & 11,7 & \\
\hline 5 & & 18,2 & 18,2 & & & & & & & & & 9,1 & 27,2 & & & & & 9,1 & 9,1 & & & 9,1 & \\
\hline 6 & 16,7 & & & 5,6 & & & & & & 11,1 & 11,1 & & 16,7 & & 11,1 & & 11,1 & 16,7 & & & & & \\
\hline 9 & 12,5 & & & & & & & & & & & 37,5 & 25,0 & & 125 & & & 12,5 & & & & & \\
\hline 10 & 7,7 & 7,7 & & & & 15,4 & 15,4 & & & & 7,7 & 7,7 & 30,7 & & 7,7 & & & & & & & & \\
\hline 11 & & 10 & & 10 & & 20 & 20 & 10 & & 10 & & & 10 & & 10 & & & & & & & & \\
\hline 12 & 7,1 & 3,6 & & & 3,6 & & & & 10,7 & 3,6 & & & 25,1 & 14,3 & & & 17,8 & 7,1 & & & 7,1 & & \\
\hline 13 & 5,8 & 5,8 & 7,7 & 1,9 & 5,8 & 5,8 & 3,8 & & 3,8 & 7,7 & 1,9 & 13,4 & & 7,7 & 7,7 & & & 5,8 & 5,8 & 1,9 & 5,8 & 1,9 & \\
\hline 14 & 16 & 16 & 8 & 4 & & & 16 & & & & & & 16 & & & & 8 & 4 & & & & 8 & 4 \\
\hline 19 & & & 4,8 & 9,5 & 4,8 & & & & & & 4,8 & 9,5 & 14,2 & & 9,5 & & & 4,8 & & & & 23,9 & 14,2 \\
\hline 20 & & & & & & & & & & & & & 20,0 & & 20,0 & & & 40,0 & & & & & 20,0 \\
\hline 21 & 5,0 & 15,0 & & 5,0 & & & 25,0 & 25,0 & & & & & 15,0 & & 5,0 & & & 5,0 & & & & & \\
\hline 22 & & & 5,6 & 11,2 & 5,6 & & & & & & & 11,2 & 5,6 & 5,6 & & & & 16,0 & 28,0 & & & & 11,2 \\
\hline 23 & & 15,4 & & & & & 7,7 & & & & & & & 7,7 & 15,4 & & 7,7 & 7,7 & 15,4 & 7,7 & & & \\
\hline
\end{tabular}


ісцевість з ндрових рівнин. рочищ. 1. оверхні горбів з дерново-сл бкопідзолистими глеюв тими супіщ ними грунт ми н флювіогляці льних відкл д х, розор ні. 2. ідвищені плоскі поверхні з дерново-сл бкопідзолистими глеюв тими супіщ ними грунт ми н флювіогляці льних відкл д х, розор ні. 3. ідвишені плоскі поверхні з дерново-сл бкопідзолистими глейовими зв'язнопіш ними грунт ми н флювіогляці льних відкл д х під дубово-сосновими і дубово-вільхово-сосновими різнотр вно-зеленомоховими ліс ми. 4. ідвищені плоскі поверхні з дерново-сл бкопідзолистими глейовими супіщ ними грунт ми н флювіогляці льних відкл д х, розор ні. 5. л бкознижені поверхні з дерновосл бкопідзолистими глейовими супіщ ними грунт ми н флювіогляці льних відкл д х з дубово-вільхово-сосновими м линово-кропивними м линово-безщитниково-кв сеницевими ліс ми. 6. л бкознижені плоскі поверхні з дерново-середньопідзолистими глеюв тими супіщ ними грунт ми н флювіогляці льних відкл д х, розор ні. 7. л бкознижені плоскі поверхні 3 дерново-сл бкопідзолистими глейовими супіщ ними грунт ми н флювіогляці льних відкл д $\mathrm{x}$, розор ні. 8. нижені плоскі поверхні з підзолистими дерновими глеюв тими грунт ми н флювіогляці льних відкл д х, розор ні. . ісцевість сл бкохвилястої денуд ційної рівнини з близьким з ляг нням к рбон тних порід. рочищ. 9. оверхні горбів з дерново-к рбон тними середньосуглинковими грунт ми н елювії к рбон тних порід. 10. ідвищені поверхні з дерновими глибокими глеюв тими легкосуглинковими грунт ми н флювіогляці льних відкл д х, підстеленими лучним мергелем, розор ні. 11. нижені плоскі поверхні з дерновими глибокими к рбон тними глеюв тими легкосуглинковими грунт ми н флювіоглящі льних відкл д $\mathrm{x}$, підстелених лучним мергелем. 12. нижені плоскі поверхні з лучними к рбон тними легкосуглинковими глеюв тими грунт ми н флювіогляці льних і озерних відкл д х, підстелених лучним мергелем, розор ні. . ісцевість міжрічкових знижень. рочищ. 13. л бкопідвищені поверхні 3 дерновими глибокими зв'язнопіщ ними грунт ми н флювіогляці льних відкл д х, під п совищ ми. 14. онижені поверхні з дерновими глибокими глейовими супіщ ними грунт ми н озерних відкл д х, під П совищ ми. 15. оверхні 3 пл в 3 дерновими глибокими глейовими зв'язнопіщ ними супіщ ними грунт ми н суч сному лювії, під п совищ ми. 16. нижені поверхні з лучними сл бош рув тими супіщ ними грунт ми н озерних відкл д х. 17. оверхні з пл в з лучними ш рув тими супіш ними грунт ми н суч сному лювії. 18 . нижені плоскі поверхні 3 лучними глейовими супіщ ними і легкосуглинковими грунт ми н флювіогляці льних і озерно-болотних відкл д х. 19. ниження з лучними глейовими легко- і середньосуглинковими грунт ми н озерних і болотних відкл д х. 20. изькі поверхні з лучно-болотними легкосуглинковими грунт ми н озерних відкл д х під п совищ ми і сінож тями. 21. изькі поверхні з лучно-болотними середньосуглинковими грунт ми н озерних і болотних відкл д х під п совищ ми і сінож тями. 22. изькі плоскі поверхні з болотними осушеними супіщ ними грунт ми н флювіогляці льних і озерноболотних відкл д х під березово-вільховими з домішкою сосни безщитниково-кропивними ліс ми. 23. уже низькі поверхні з торфово-болотними грунт ми і торфовищ ми низинними н озерних відкл д х. 
ндш фтні сусідств цошинсько- мереківської ключової ділянки, \% сумісної зустрічності

\begin{tabular}{|c|c|c|c|c|c|c|c|c|c|c|c|c|c|c|c|c|}
\hline $\begin{array}{r}\text { ид } \\
\text { уро- } \\
\text { чищ }\end{array}$ & 1 & 2 & 3 & 4 & 5 & 6 & 7 & 8 & 9 & 10 & 11 & 12 & 13 & 14 & 15 & 16 \\
\hline 1 & & & & 31,80 & 59,09 & & & & & 4,55 & 4,55 & & & & & \\
\hline 2 & & & & 22,22 & 77,77 & & & & & & & & & & & \\
\hline 3 & & & & 33,33 & 33,33 & & & & & & & & & & 33,33 & \\
\hline 4 & 35,00 & 10,00 & 5,00 & & 25,00 & 10,00 & & & & 5,00 & & & 5,00 & & 5,00 & \\
\hline 5 & 28,26 & 15,22 & 2,17 & 10,87 & & 13,04 & & & & 4,35 & & & 2,17 & 13,04 & 8,70 & 2,17 \\
\hline 6 & & & & 22,22 & 66,66 & & & & & 11,11 & & & & & & \\
\hline 7 & & & & & & & & 11,11 & 44,44 & 11,11 & & 22,22 & & 11,11 & & \\
\hline 8 & & & & & & 5,88 & 12,5 & & 25 & 12,5 & & 37,5 & & 12,5 & & \\
\hline 9 & & & & & & & 11,11 & 16,67 & 33,33 & 11,11 & & & & 16,67 & 5,55 & 5,55 \\
\hline 10 & 5,88 & & & 5,88 & 11,76 & & 5,88 & 5,88 & 17,65 & & 5,88 & 11,76 & & 5,88 & 11,76 & 5,88 \\
\hline 11 & 33,33 & & & & & & & & 33,33 & 33,33 & & & & & & \\
\hline 12 & & & & & & & 21,05 & 10,53 & & 15,79 & 5,26 & 31,58 & & 15,79 & & \\
\hline 13 & & & & 50,00 & 50,00 & & & & & & & & & & & \\
\hline 14 & & & & & 35,29 & & 5,88 & 5,88 & 17,65 & 5,88 & & 17,65 & & & 5,88 & 5,88 \\
\hline 15 & & & 10,00 & 10,00 & 40,00 & & & & & 20,00 & & 10,00 & & 10,00 & & \\
\hline 16 & & & & & 25,00 & & & & & 25,00 & & 25,00 & & 25,00 & & \\
\hline
\end{tabular}


ісцевість сл бкодренов них лесових $n$ сом. рочищ. 1. л бковипуклі поверхні горбів зі світло-сірими лісовими глеюв тими грунт ми н лесоподібних великопилув тих легкосуглинкових відкл д х, розор ні. 2. идовжені поверхні горбів зі світло-сірими т сірими опідзоленими глеюв тими грунт ми н лесоподібних суглинк х, розор ні. 3. л бковипуклі поверхні коротких п сом з дерново-к рбон тними грунт ми н елюві к рбон тних порід, розор ні. 4. ологі схили сл бкопідвищених п сом з сірими лісовими глеюв тими змитими грунт ми н лесоподібних легкосуглинкових відкл д х, розор ні. 5. ідвищені сл бкохвилясті н хилені межиріччя з сірими лісовими глеюв тими грунт ми н лесоподібних легкосуглинкових відкл д х, розор ні. 6. нищ лощин т б лок з лучно-болотними грунт ми під п совищ ми і сінож тями. . iсцевість сл бкохвилястої з ндрової рівнини. рочищ. 7. ідвищені сл бкохвилясті межиріччя з дерново-сл бкопідзолистими глеюв тими грунт ми н водно-льодовикових відкл д х, розор ні. 8. л бкохвилясті межиріччя, ускл днені мережею струмків т к н лів, 3 дерново-сл бкопідзолистими глейовими осушеними в комплексі з дерновими глибокими глейовими осушеними грунт ми н флювіогляці льних відкл д $\mathrm{x}$ під березовососновими зл ково-зеленомоховими ліс ми. 9. нищ лощин т б лок з лучними зв'язнопіщ ними грунт ми н водно-льодовикових відкл д х під п совищ ми і сінож тями. . ісцевість сл бкохвилястої денуд ційної рівнини з близьким з ляг нням к рбон тних порід. рочищ. 10. рипідняті хвилясті поверхні, ускл днені мережею к н лів, з лучними к рбон тними грунт ми, підстелені середньосуглинковим лучним мергелем, розор ні. 11. рипідняті погорбов ні поверхні з дерновими глибокими глейовими осушеними грунт ми н флювіогляці льних вілкл д х т лучному мергелі, розор ні. 12. лоскі поверхні з лучними к рбон тними грунт ми н лучному мергелі під різнотр вно-зл ковими лук ми. $V$. ісцевість річкових долин $і$ знижень. рочищ. 13. нищ річкових долин з лучними глейовими н митими грунт ми, підстеленими лучним мергелем, під різнотр вними лук ми. 14. нищ потоків з дерновими глибокими глейовими к рбон тними осушеними грунт ми, підстеленим лучним мергелем т суч сним лювієм, під сінож тями. 15. оверхні міжп смових знижень, усп дков ні річковими долин ми, 3 дерновими глибокими глейовими к рбон тними осушеними грунт ми, підстеленими лучним мергелем, розор ні. 16. изькі поверхні міжп смових знижень 3 лучно-болотними к рбон тними осушеними грунт ми н лучному мергелі, під п совищ ми. 
одноч с, н відміну від попередньої ключової ділянки, є низк урочищ з м лою кількістю сусідів і яскр во вир женим домін нтом. л кількість сусідів вл стив горбів і днищ лощин т б лок. рочищ горбів, по-перше, м ють невеликі розміри, , по-друге, є ч стиною певної припіднятої поверхні більших розмірів, що робить пї пріоритетним сусідом і різко скорочує дотичність з іншими л ндш фтними комплекс ми. риродні комплекси видовжених поверхонь горбів зі світло-сірими т сірими лісовими грунт ми (вид 2) м ють лише дв урочищ -сусіди, з одним із яких - підвищені сл бкохвилясті межиріччя з сірими лісовими глеюв тими грунт ми (вид 5) тр пляються у 77,77 \% вип дків. орби, які предст влені виду 1, м ють більшу різном нітність місцеположень, тому ч стк сусід -домін нт зменшується до 59,09 \%.

ричиною м лої кількості сусідів в урочищ днищ лощин і б лок є невеликі поздовжні розміри схилів, н яких вони з кл дені й розвив ються, т кож близькість б зису ерозії. виду 6 межує тільки з трьом вид ми і з одним із них - підвищені сл бкохвилясті сл бкон хилені межиріччя з сірими лісовими глеюв тими грунт ми (вид 5) - у $66,66 \%$ вип дків. умісн зустрічність з двом іншими -22,2 і 11,11\%.

риблизно в т кому ж ст новищі виду 13 - днищ потоків 3 дерновими глибокими глейовими к рбон тними грунт ми. они перетин ють поверхні двох видів урочищ, проте в одн ковій кількості вип дків (по $50 \%$ ).

і л ндш фтні комплекси, які м ють чітко вир жених сусідів, можуть бути їхніми індик тор ми. ючи відомості про х р ктерні сусідств, можн з'ясовув ти видову н лежність л ндш фтного комплексу без проведення польових досліджень. ведені в т блицях пок зники сумісної зустрічності тих чи інших урочищ, окрім того, що ілюструють, які л ндш фтні комплекси тр пляються один з одним, які не поєднуються між собою, відобр ж ють міру вірогідності цього зв'язку. нші кількісні пок зники сусідств - мір близькості і питом протяжність, н ліз яких не висвітлено в пр ці, дет лізують х р ктер визн чених відношень. рім того, інтерес ст новлять міжл ндш фтні зв'язки як т кі, безвідносно до їхньої ідентифік ційної спроможності, оскільки, розкрив ючи ще один спект л ндш фтної будови території, підвищують інформ ційну цінність л ндш фтної к рти. і д ні можуть бути використ ні і для скл д ння л ндш фтних к рт н генетично подібні ділянки лого олісся і поліських л ндш фтів уз г лі.

1. обр . . н ліз л ндш фтних меж івденно- хідного риму: втореф. дис. н здобуття н ук. ступеня к нд. геогр. н ук : спец. 11.00 .01 “фізичн геогр фія, геофізик т геохімія л ндш фтів”/ обр етян лентинівн . - імферополь, 2001. - 20 с.

2. икторов . . исунок л ндш фт / . . икторов. - . : ысль. $-1986 .-180$ с.

3. икторов . . оль л ндш фтного рисунк при экстр поляции индик ционного зн чения эктоярусов природных территори льных комплексов (н примере ург йской стр ны) / . . икторов // ндш фтоведение: теория и пр ктик : н уч. сб. “ опросы геогр фии”. - . : ысль, 1982. - ып. 121. - . 147-153.

4. еренчук .. ольові геогр фічні дослідження : н вч. посібник / . еренчук, . . ковськ , . . опчієв. - . : ищ школ , 1975. -248 с.

5. $в$ шутин . . н лизу л ндш фтной структуры физико-геогр фических р йонов / . . шутин , . . икол ев // естн. оск. ун-т . ер. геогр. - 1969. - № 4. - . 49-59.

6. в шутин . . онтр стность л ндш фтной структуры и некоторые спекты ее изучения / . . в шутин , . . икол ев // естн. оск. ун-т . ер. геогр. - 1971. - № 5. - . 70-77. 
7. 3 нцев . . ростр нственн я изменчивость л ндш фтных и геокриологических условий естественных и н рушенных экосистем северной т йги п дной ибири / . . 3 нцев // риосфер емли. - 2007. - . 11. - № 2. - . 14-18.

8. имонов . . днородность, сортиров нность и их меры / . . имонов // тем тические методы в геогр фии: сб. н уч. тр. - 3 нь, 1971. - . 28-33.

9. имонов . . еогр фическое соседство и методы его измерения / . . имонов // естн. оск. ун-т . ер. геогр. - 1975. - № 4. - . 13-18.

10. ридл нд . . труктур почвенного покров / . . ридл нд. - . : ысль, 1984. - 423 с.

11. орошев . . ценк устойчивости л ндш фтов 6 ссейн p. кс н ( ентр льный вк 3) / . . орошев // естн. оск. ун-т . ер. 5. еогр фия. - 1995. - №1. - . 81-87.

m ття: н дійшл до редколегї̈ 17.09.2011 прийнят до друку 20.09.2011

\section{FEATURES OF THE LANDSCAPE NEIGHBOURHOOD IN THE WERSTERN PART OF SMALL POLISSYA}

\section{O. Zagulska}

Ivan Franko National University of Lviv, . Doroshenko St., 41, UA - 79000 Lviv, Ukraine

On an example of two model areas features of the landscape neighbourhood in the western part of Small Polissya and the cause of its formation are opened. Degree of co-occurrence of those or other natural complexes defined as a share from all inherent in them neighbourhood, accepted for $100 \%$. The indicators of co-occurrence of those or other natural complexes resulted in tables illustrate, what landscape complexes occur with each other and which aren't combined among themselves, and also show degree of probability of this connection. It is established that within the Ratinska model areas each kind of natural complexes has a considerable quantity of neighbors that has pulled behind itself low indicators of frequency of occurrence with each of them. On the model areas put in Pasmove Pobuzhzhya, a number of natural complexes has small quantity of neighbors and strongly pronounced a dominant. These are landscape complexes of hills and the bottoms of hollows and beams. Having data on the characteristic neighbourhoods, it is possible to find out a specific accessory of a landscape complex without carrying out of field researches. It is shown mainstreams of application of knowledge of the landscape neighbourhoods: research of genesis of landscape complexes, physical-geographical division into districts, landscape indication, thematic data processing of remote sounding of the Earth, geographical forecasting.

Key words: Small Polissya, landscape complex, landscape drawing, the landscape neighbourhood, co-occurrence. 


\section{- гульск я}

ьвовский н иион льный университет имени в н р нко, ул. . орошенко, 41, г. ьвов, 79000, кр ин

примере двух ключевых уч стков р скрыто особенности л ндш фтного соседств в 3 п дной ч сти лого олесья и причины его формиров ния. тепень совместной встреч емости тех или иных урочищ определяли к к долю от всех присущих им соседствов ний, принятых 3 $100 \%$. риведенные в т блиц х пок з тели совместной встреч емости тех или иных урочищ иллюстрируют, к кие л ндш фтные комплексы встреч ются друг с другом, которые не сочет ются между собой, т кже пок зыв ют степень достоверности этой связи. ст новлено, что в p мк х тинского ключевого уч стк к ждый вид урочищ имеет большое количество соседей, что потянуло $з$ собой низкие пок з тели ч стоты встреч емости с к ждым из них. ключевом уч стке, з ложенном в рядовом обужье, ряд урочищ имеет м лое количество соседей и ярко выр женного домин нт . то л ндш фтные комплексы холмов и днищ лощин и б лок. мея сведения о х р ктерных соседств х, можно выяснять видовую прин длежность л ндш фтного комплекс без проведения полевых исследов ний. ок 3 но гл вные н пр вления применения зн ний о л ндш фтных соседств х: исследов ние генезис л ндш фтных комплексов, физикогеогр фическое р йониров ние, л ндш фтн я индик ция, тем тическ я обр ботк д нных дист нционного зондиров ния емли, геогр фическое прогнозиров ние.

лючевые слов : лое олесье, л ндш фтный комплекс, л ндш фтный рисунок, л ндш фтное соседство, совместн я встреч емость. 